\title{
Young consumer awareness of halal food in Indonesia
}

\author{
Muhammad Khaliqi ${ }^{1, *}$, and Tasya Chairuna Pane ${ }^{1}$ \\ ${ }^{1}$ Agribusiness Department, Faculty of Agriculture, Universitas Sumatera Utara, Jl. Dr. Ahmad Sofian \\ No. 3, Medan, 20155, North Sumatera, Indonesia
}

\begin{abstract}
The future of the halal product industry in Indonesia is determined by Indonesian consumers' demand. Young consumers have a significant role in the development of halal products because 25 percent of consumers in Indonesia are young consumers. Therefore, this research focused on the awareness of young Indonesian consumers to halal products. The purpose of this study was to analyse the factors affecting the awareness of young Indonesian consumers. The data used were crosssection data collected from young consumers of halal products for the 1725 age group by using 157 respondents. Convenience sampling was used to determine the interview sample. Data were analysed using the Structural Equation Model method. The results show that the young consumer awareness of halal food in Indonesia was high. The factors affecting young consumer awareness were health and religion knowledge.
\end{abstract}

\section{Introduction}

Manufacture of Indonesian food gives high attention to halal food products. Halal product is a product that can provide a guarantee the quality, safety, and hygiene of products to the consumers [1]. For a Muslim, eating halal food is an obligation which is prescribed by religion [2]. By thus, the consumption of halal products becomes a picture of faith and devotion level to follow the commands of God. Consumer understanding of halal products is influenced by individuals, social environment, and other factors such as food health assurance and food quality [3]. Halal product request in the countries dominated by muslim is automatically getting higher compared with countries other. However, growth in the consumption of halal products in other countries is relatively increasing [4]. Statistics proves that the demand for halal products and services is increasing and fast [5]

Indonesia, as one of the largest Muslim countries, has a potential market in developing halal products. Demographic condition of Indonesia reveals that as much as 25 percent of the people of Indonesia in domination by the young or the generation of millennials. The high proportion of young consumers indicates that the halal product in Indonesia is determined by younger consumers, meaning that youth will become halal consumers in the present and the future ahead. Therefore, the role of young consumers is relatively high in

*Corresponding author: muhammadkhaliqi@usu.ac.id 
developing halal products in Indonesia. Understanding, knowledge, and awareness of young consumers of halal products are the indicators of the sustainability of halal product development in Indonesia.

Awareness of young consumers of halal products is a human perception and response to the conditions of products eaten, drunk, and used [6]. Consumer awareness is the first step in the buying process - consumers who initially do not know about the finished product will make a purchase mindlessly [7]. Based on the background, the research aimed to identify factors affecting the awareness level of young muslim consumers in Indonesia.

\section{Materials and methods}

This study used a questionnaire to collect research data. In general, the questionnaire was formed by considering variables affecting the level of young consumers awareness of halal products. Overall questions represented the variables compiled by literature review. The questionnaire was divided into two parts. The first part explained the demographic conditions of the respondents. The second part was a question describing the growing level of consumer awareness of halal products, religion knowledge, religious belief, and health reason. The type of data used in this study was ordinal data. Questions of questionnaire were measured using a scale Likert (1: strongly disagree up to 7: strongly agree). Respondents were selected based on accidental sampling. Accidental sampling was one of the techniques of non-probability sampling, where respondents selected were subjective, in order to represent the population. The total respondents from this study were 157 respondents.

Data on 157 respondents were analyzed using the Partial Least Square-Structural Equation Model (PLS-SEM). PLS-SEM is one of the techniques of explanatory variables [8]. PLS-SEM is also a technique of regression used to analyze the abstract variables (not afford rating directly), so that the latent variables can be explained. The latent variables of this research were young consumer awareness, religion belief, religions knowledge, and health reason. (Fig. 1.)

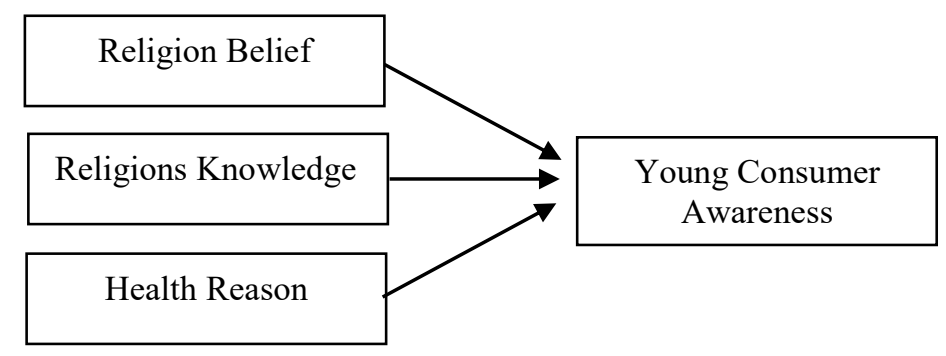

Fig. 1. Conceptual Framework

\section{Result and discussion}

\subsection{Demographic analysis}

Table 1 shows the profile of the 157 respondents who were interviewed. A total of 73 $(46 \%)$ respondents were male and $84(54 \%)$ of them were female. Most of the respondents had a bachelor degree, namely of $81 \%$. 
Table 1. Demographic profile of respondent $(n=157)$

\begin{tabular}{|c|c|c|c|}
\hline Demographic Variables & Details & Frequency & Percentage (\%) \\
\hline \multirow{3}{*}{ Gender } & Male & 73 & 46 \\
\cline { 2 - 4 } & Female & 84 & 54 \\
\hline \multirow{4}{*}{ Education } & Senior High School & 4 & 3 \\
\cline { 2 - 4 } & Diploma-1 & 11 & 7 \\
\cline { 2 - 4 } & Diploma-3 & 13 & 8 \\
\cline { 2 - 4 } & Bachelor & 127 & 81 \\
\cline { 2 - 4 } & Master & 2 & 1 \\
\hline
\end{tabular}

\subsection{Partial least square analysis}

\subsubsection{Outer model evaluation}

The outer model evaluation aimed to measure how much the manifest variable could explain latent variables. If the value of the manifest variable was smaller than 0.5 , then the manifest variables had to drop out of the model early $[9,10]$. The initial model in this study consisted of 10 religious belief manifest variables, 5 health reason manifest variables, 7 religious knowledge manifest variables, and 9 young consumer awareness manifest variables. These manifest variables were the variables describing latent variables (Fig. 2).

Average Variance Extracted (AVE) was used to see the validity of the model that had been formed. Rated AVE should be more substantial than 0.5 , so that the overall variables existing in questionnaire can be said valid. Subsequently, the value of Composite Reliability was analyzed to measure how the reliability of the model was formed. The composite reliability value should be greater than 0.6 which showed reliability to answer the question of research.

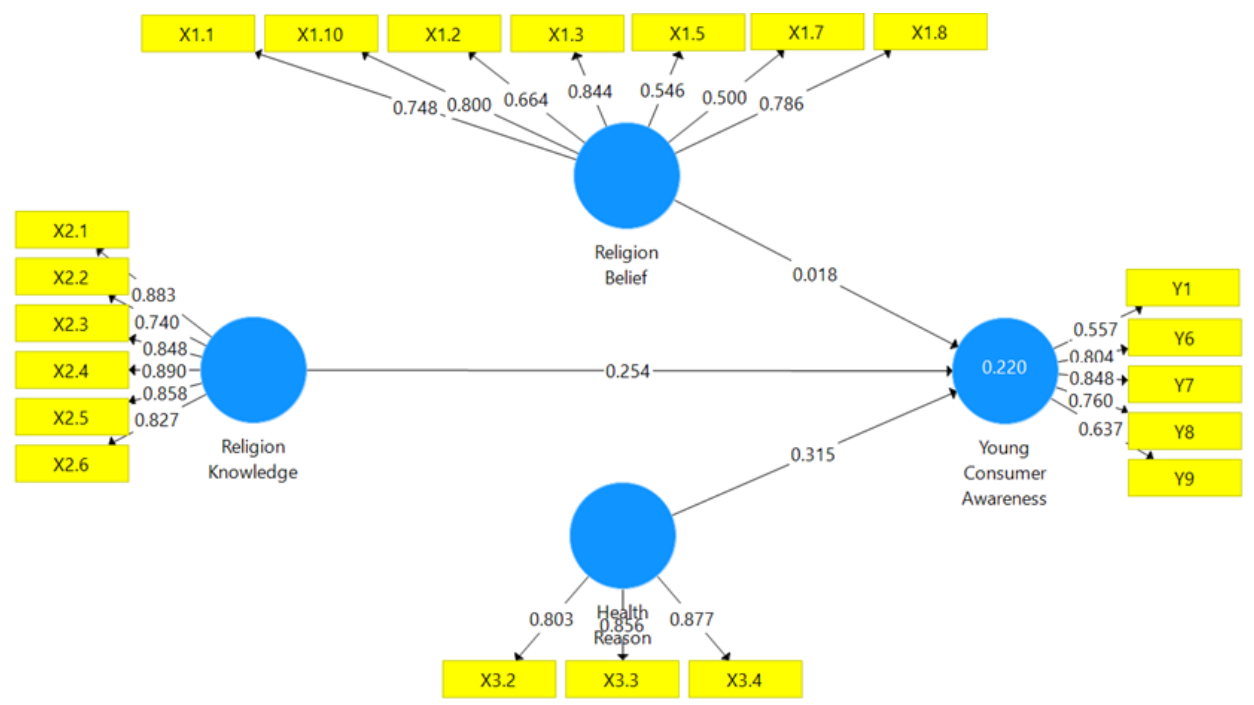

Fig. 2. Loading Factor Result and PLS Final Model 
Table 2. Average variance extracted and composite reliability

\begin{tabular}{|c|c|c|}
\hline Variables & Composite Reliability & $\begin{array}{c}\text { Average Variance Extracted } \\
\text { (AVE) }\end{array}$ \\
\hline Young Consumer Awareness & 0.848 & 0.532 \\
\hline Religion Knowledge & 0.936 & 0.709 \\
\hline Religion Belief & 0.873 & 0.503 \\
\hline Health Reason & 0.883 & 0.715 \\
\hline
\end{tabular}

\section{2. 2 Inner model evaluation}

The inner model of evaluation was an analysis used to look at the suitability of the formed model. Results of inner models showed value of 0.205 . This value illustrates that the model formed was appropriate, which included the good of fit moderate modelling.

\section{2. 3 Hypothesis testing}

This study aimed to look at the factors influencing young consumers' awareness of halal products. From the literature review, it was obtained that three variables influenced the awareness of young consumers towards halal products, namely religious belief, religious knowledge, and health reason. In statistical research, it could be proven that the religious knowledge and health reason influenced significantly, while religion belief did not affect it significantly with the significance value of 0.05 . The results of hypothesis testing are presented in Table 3.

Table 3. Hypothesis result testing

\begin{tabular}{|c|c|c|c|}
\hline Variable & Coefficient & p-value & Conclusion \\
\hline Religion Belief & 0.018 & 0.870 & Not Significant \\
\hline Religion Knowledge & 0.254 & 0.015 & Significant \\
\hline Health Reason & 0.315 & 0.000 & Significant \\
\hline
\end{tabular}

The results of the hypothesis test show that religious knowledge and health reason had a positive influence on the awareness of young consumers on halal products. Research was managed to prove its influence positively. Where the results of the study earlier showed that knowledge of religion is one of the elements that are important in influencing the awareness of consumers young to products halal [11]. Consumer knowledge can shape the perception of young consumers of halal products [12].

Not only knowledge, health reason was also a factor affecting the awareness of young consumers of halal products. Product halal provides a guarantee of the quality and cleanliness of the consumed food. Consumers presume that the health of the consumed products is essential in determining the health of consumers $[13,14]$. The bad quality of food will provide contrary side effects toward consumers. Every product that has passed the halal certification can be considered as clean food, so that it can be concluded that halal products are strictly related to the cleanliness, safety, and high quality of the product [6].

\section{Conclusion}

It can be concluded that the awareness level of young consumers to halal products was influenced by two factors, namely religion knowledge and health factors. The second factor could give positive effect for the consumers. This illustrates that the halal certification of 
products was important for the consumers. The confidence of consumers in terms of religion as well as the aspect of health would open up the opportunities for halal products market. Therefore, the halal products were consumed by not only young muslin consumers, but also the various types of consumers.

The research was funded by Universitas Sumatera Utara through the Non-PNBP Fund Fiscal in 2019 based on the Implementation Contract of Universitas Sumatera Utara TALENTA Research Fiscal in 2019 between the Rector and the Chairman of Universitas Sumatera Utara Research Institute Number: 4167/UN5.1.R/PPM/2019 dated April 1 $1^{\text {st }} 2019$.

\section{References}

1. M. Aliff, A. Majid, I. Hafifi, Z. Abidin, H. Adilin, M. Abd, and C. T. Chik, J. Appl. Environ. Biol. Sci. 5, 50 (2015)

2. D. A. Kurniawati and H. Savitri, J. Islam. Mark. 11, 531 (2019)

3. Phuah Kit Teng, Wan Jamaliah Wan Jusoh, H. K. Siong, and M. M. Mesbahi, 3rd Int. Conf. Manag. Proceeding 89 (2013)

4. A. M. Bashir, J. Islam. Mark. (2019)

5. K. A. Rahman, Glob. J. Manag. Bus. Res. 18, 36 (2018)

6. A. R. Ambali and A. N. Bakar, Procedia - Soc. Behav. Sci. 121, 3 (2014)

7. A. M. Bashir, A. Bayat, S. O. Olutuase, and Z. A. Abdul Latiff, J. Food Prod. Mark. 25, 26 (2019)

8. W. Ahmed, A. Najmi, H. M. Faizan, and S. Ahmed, Br. Food J. 121, 492 (2019)

9. J. F. Hair, C. M. Ringle, and M. Sarstedt, J. Mark. Theory Pract. 19, 139 (2011)

10. J. F. Hair, R. E. Anderson, B. J. Babin, and W. C. Black, (2010)

11. M. Said, F. Hassan, R. Musa, and N. A. Rahman, Procedia - Soc. Behav. Sci. 130, 120 (2014)

12. A. R. Rao and W. A. Sieben, J. Consum. Res. 19, 256 (1992)

13. A. N. Ahmad, A. A. Rahman, and S. A. Rahman, Int. J. Soc. Sci. Humanit. 5, 10 (2014)

14. K. Bonne, I. Vermeir, F. Bergeaud-Blackler, and W. Verbeke, Br. Food J. 109, 367 (2007) 